\title{
Altered transcriptome signature of phenotypically normal skin fibroblasts heterozygous for CDKN2A in familial melanoma: relevance to early intervention
}

\author{
Meiyun Fan ${ }^{1 *}$, Susan R. Pfeffer ${ }^{*}$, Henry T. Lynch ${ }^{2}$, Pamela Cassidy ${ }^{3}$, Sancy \\ Leachman ${ }^{3}$, Lawrence M. Pfeffer ${ }^{1}$, and Levy Kopelovich ${ }^{4}$ \\ ${ }^{1}$ Department of Pathology and Laboratory Medicine, and the Center for Cancer Research, University of Tennessee Health \\ Science Center, Memphis, TN, USA \\ 2 Department of Preventive Medicine, Creighton University, Omaha, NE, USA \\ ${ }^{3}$ Melanoma \& Cutaneous Oncology Program, Huntsman Cancer Institute, and Department of Dermatology, University of \\ Utah, Salt Lake City, UT, USA \\ ${ }^{4}$ Division of Cancer Prevention, National Cancer Institute, Bethesda, MD, USA \\ * Contributed equally to the work \\ Correspondence to: Levy Kopelovich, email: kopelovich@nih.gov \\ Correspondence to: Lawrence M.Pfeffer, email: Ipfeffer@uthsc.edu \\ Keywords: Familial Melanoma/ gene expression/ CDKN2A/ p16/ Mutations/ Melanoma \\ Received: December 14, 2012, Accepted: January 18, 2013, $\quad$ Published: January 19, 2013
}

Copyright: ( ) Fan et al. This is an open-access article distributed under the terms of the Creative Commons Attribution License, which permits unrestricted use, distribution, and reproduction in any medium, provided the original author and source are credited.

ABSTRACT:

Familial melanoma (FM) is a dominantly heritable cancer that is associated with mutations in the tumor suppressor CDKN2A/p16. In FM, a single inherited "hit" occurs in every somatic cell, enabling interrogation of cultured normal skin fibroblasts (SFs) from FM gene carriers as surrogates for the cell of tumor origin, namely the melanocyte. We compared the gene expression profile of SFs from FM individuals with two distinct CDKN2A/p16 mutations (V126D-p16 and R87P-p16) with the gene expression profile of SFs from age-matched individuals without p16 mutations and with no family history of melanoma. We show an altered transcriptome signature in normal SFs bearing a single-hit inherited mutation in the CDKN2A/p16 gene, wherein some of these abnormal alterations recapitulate changes observed in the corresponding cancer. Significantly, the extent of the alterations is mutation-site specific with the R87P-p16 mutation being more disruptive than the V126D-p16 mutation. We also examined changes in gene expression after exposure to ultraviolet (UV) radiation to define potential early biomarkers triggered by sun exposure. UV treatment of SFs from FM families induces distinct alterations in genes related to cell cycle regulation and DNA damage responses that are also reported to be dysregulated in melanoma. Importantly, these changes were diametrically opposed to UV-induced changes in SF from normal controls. We posit that changes identified in the transcriptome of SF from FM mutation carriers represent early events critical for melanoma development. As such, they may serve as specific biomarkers of increased risk as well as molecular targets for personalized prevention strategies in high-risk populations.

\section{INTRODUCTION}

Skin cancer is the most common human cancer worldwide [1]. Melanoma is a highly aggressive form of skin cancer that accounts for $\sim 80 \%$ of skin cancer-related deaths in the US. Genetic predisposition and UV radiation are the major risk factors for skin cancer, including melanoma [2]. The clustering of melanoma within a single family that is characterized by multiple atypical nevi is referred to as familial melanoma (FM) [3]. FM is likely to occur at an early age, in multiple generations and with high penetrance, resulting in a 35- to 70-fold 
TABLE 1: Normal and familial melanoma individuals included in this study

\begin{tabular}{|c|c|c|c|}
\hline Patient & Gender & Age & $\begin{array}{l}\text { CDKN2A/p16 } \\
\text { mutation }\end{array}$ \\
\hline N1 & Male & 51 & None \\
\hline N2 & Male & 51 & None \\
\hline $\mathrm{F} 1$ & Male & 18 & V126D \\
\hline $\mathrm{F} 2$ & Male & 52 & V126D \\
\hline F3 & Male & 45 & V126D \\
\hline $\mathrm{F} 4$ & Female & 36 & R87P \\
\hline F5 & Female & 73 & R87P \\
\hline F6 & Female & 62 & R87P \\
\hline \multicolumn{4}{|c|}{$\begin{array}{l}\mathrm{N} \text {, normal individual who has no family history } \\
\text { of melanoma } \\
\text { F, familial melanoma mutation carrier }\end{array}$} \\
\hline
\end{tabular}

increase in the risk of developing melanoma $[4,5]$. Significantly, a proclivity towards pancreatic cancer is also evident in these families [6-9].

CDKN2A mutations occur in approximately 20-
$40 \%$ of melanoma-prone families world-wide [10]. Variable rates of mutations have been found in sporadic melanomas; in some studies being as high as $50 \%$ in primary lesions [11]. The CDKN2A gene locus generates two proteins through alternate slicing: $\mathrm{p} 16^{\mathrm{INK} 4 \mathrm{a}}$ and $\mathrm{p} 14^{\text {arf }}$. The $16^{\text {INK4a }}$ protein binds to CDK4 and CDK6, inhibiting their ability to phosphorylate the retinoblastoma protein. The p14 arf protein stabilizes the tumor suppressor protein p53. Collectively, these CDKN2A isoforms are potent tumor suppressors that play distinct but critical roles in cell cycle progression and apoptosis [12]

Although heterozygous loss of $\mathrm{p} 16^{\mathrm{INK} 4 \mathrm{a}}$ function is sufficient to confer a $67 \%$ lifetime risk of melanoma [13], the mechanisms responsible for tumor enhancement have yet to be clarified $[14,15]$. Mechanistic studies have been hampered by the difficulty of growing in vitro a sufficient quantity of the target cell, the human melanocyte [16]. We leveraged the presence of heterozygous CDKN2A mutations in all somatic cells of FM affected individuals to study skin fibroblasts (SFs) as surrogates for melanocytes. We reasoned that like other dominantly heritable cancers, CDKN2A mutations carried in phenotypically normal SFs from FM patients could provide clues to the early
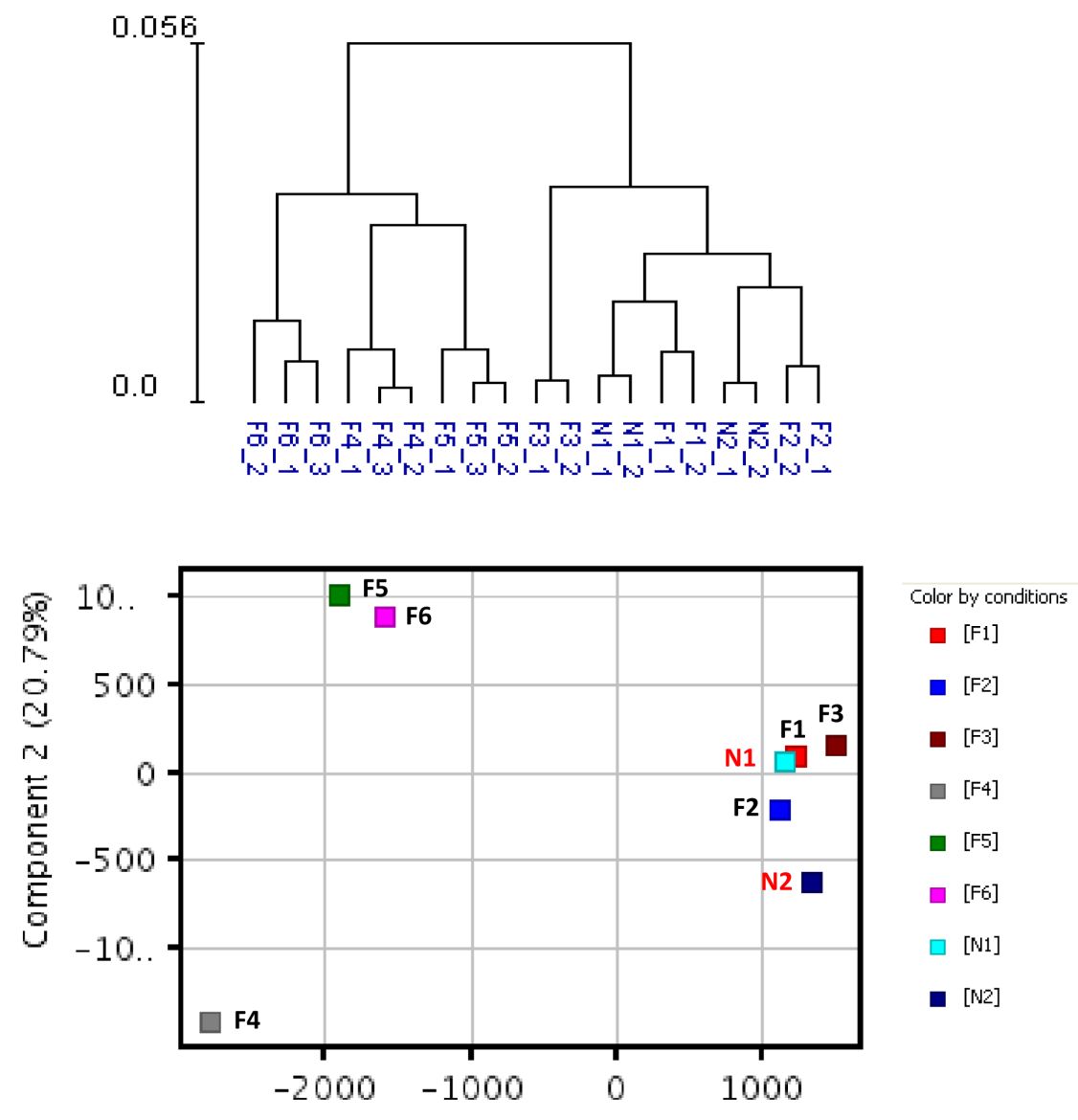

Figure 1: Hierarchical clustering and principal component analysis of gene expression data from SF cultures. Unsupervised hierarchical clustering (upper panel) and principal component analysis (lower panel) were performed on replicate cultures representing normal individuals with wild-type CDKN2A (N) or FM individuals with CDKN2A mutations (F) using normalized expression data of all probes. 
molecular events that predispose FM melanocytes to malignant conversion (for review see [17]).

In the present study we studied two FM families each with distinct CDKN2A mutations: V126D-p16 and R87P-p16. We show that gene expression profiles are altered in the phenotypically normal SFs from FM families when compared to SFs from normal controls. Further, we show that UV-irradiation of SFs from FM cohorts results in specific alterations in the expression of genes, which regulate cell cycle and DNA damage response, and that similar alterations are also observed in melanoma lesions.

Our data suggest that expression profiling can identify specific, early biomarkers of increased cancer risk in FM and in sporadic melanomas $[13,18]$. Importantly, since the molecular changes that occur in "one-hit" lesions do not include confounding secondary and tertiary tumor effects that accumulate during malignant progression, these biomarkers may also represent valuable drug targets, which can be used to guide development of personalized prevention strategies for both FM and melanomas.

\section{RESULTS}

\section{Gene expression profiling of phenotypically normal SF cultures from FM mutation carriers and unaffected controls}

Whole genome expression profiling was performed on RNA prepared from SF cultures representing three distinct groups (Table 1). Group 1 consisted of two unaffected spouse controls (N1 and N2) from FM families. They expressed wild-type CDKN2A and had no family history of melanoma; Group 2 consisted of three FM mutation carriers with a V126D-p16 mutation (F1, F2, and F3); Group 3 consisted of three FM mutation carriers (F4, F5 and F6) with a R87P-p16 mutation. Unsupervised hierarchical clustering and principal component analysis (PCA) showed that genes expressed in cultured SF from individuals within each of the three groups clustered closely together (Fig. 1). Notably, V126D-p16 heterozygous mutation carriers (Group 2), on average, cosegregated with normal controls (Group 1).

Compared to normal controls (Group 1), the expression of 136 and 1041 genes was upregulated (one-side $\mathrm{FDR}=0.1$, fold change $\geq 1.5$ ) in groups 2 and 3 , respectively, and the expression of 82 and 1363 genes was downregulated (one-side $\mathrm{FDR}=0.1$, fold change $\geq 1.5$ ) in Groups 2 and 3, respectively. A subset of 35 genes was upregulated in both groups of FM patients (Groups 2 and 3 ) compared to controls (Group 1), while expression of 22 genes was downregulated in both groups of FM patients compared to Group 1 (Figure 2). The R87P-p16 mutation (Group 3) had a much greater impact on basal gene expression than the V126D-p16 mutation (Group 2). A summary of genes differentially expressed in SF cultures from FM patients is presented in Supplementary Table 1.

Ingenuity Pathway Analysis (IPA) of genes upregulated or downregulated at baseline in Group 2 FM patients showed they were largely associated with cell proliferation, cell death, and cancer (Figure 3). More

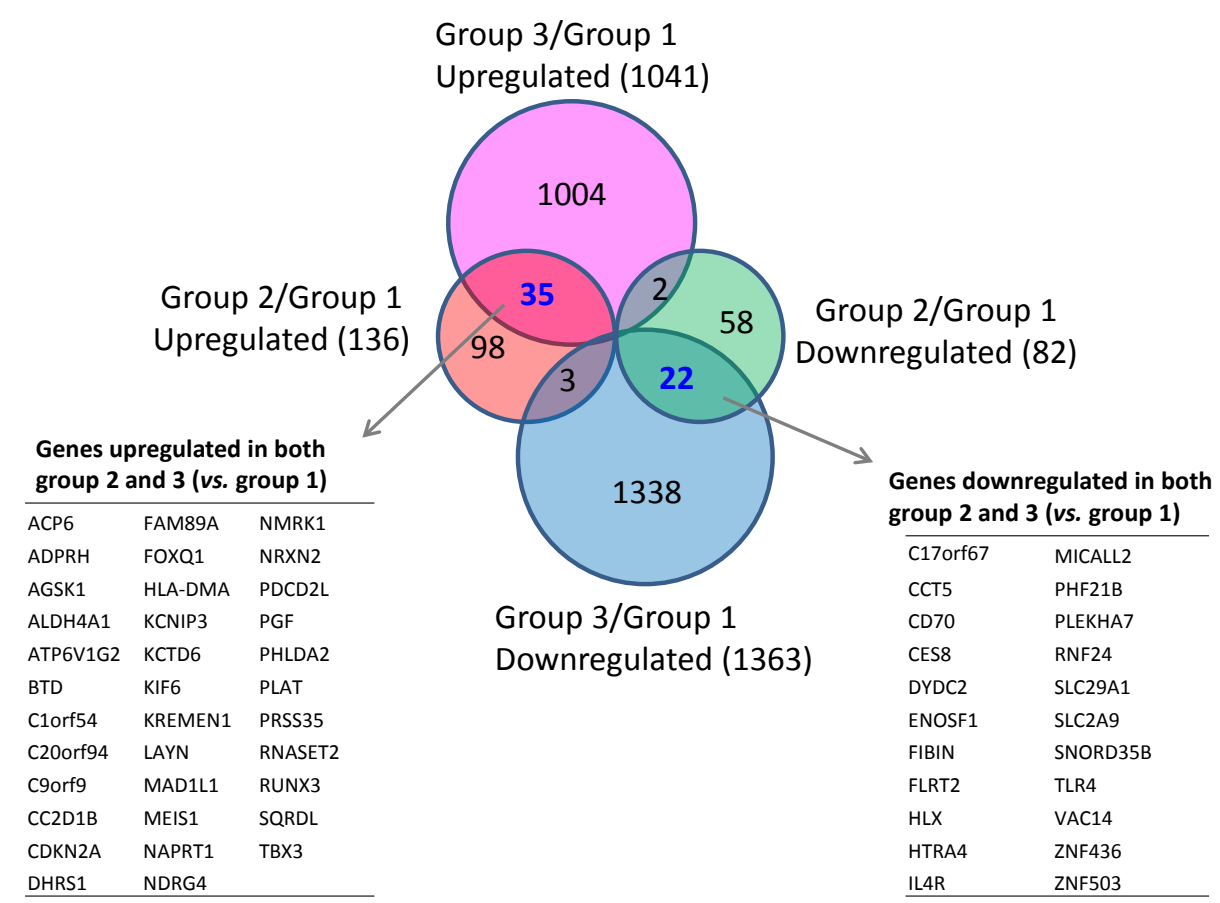

Figure 2: Differentially-expressed genes in familial SFs with distinct CDKN2A mutations. The inserted tables in the Venn Diagrams list the genes coordinately upregulated (left panel) or downregulated (right panel) in both Group 2 and Group 3 SFs in comparison to normal SFs (Group1). 
pathways were differentially affected in Group 3 than in Group 2 and were associated with cell cycle regulation, DNA damage response, DNA repair, and apoptosis. Furthermore, canonical pathways linked to normal melanocyte development and pigmentation, as well as those associated with melanoma signaling, were also affected in the Group 3 FM cohort (Figure 4).

We further examined the overlap between genes differentially expressed at baseline in both groups of SF cultures derived from FM patients and genes differentially expressed in melanoma (Gene Expression Omnibus datasets GDS1375 and GDS1989). A total of seven melanoma-associated genes were found coordinately altered in Group 2 and 3 SF cultures (Supplementary Table 1). Specifically, FLRT2 was downregulated while MAD1L1, PHLDA2, PLAT, CC2D1B, CDKN2A and RUNX3 were upregulated in both melanoma and in Group 2 and Group 3 SFs. Not surprisingly, the number of genes differentially expressed in melanoma is far more extensive than in normal-appearing SFs. The more extensive changes in melanoma likely represent secondary or tertiary changes not directly related to the etiology of melanoma, while the altered gene signatures in normalappearing SFs from FM cohorts are critical to the initiated state.

\section{UV sensitivity of normal controls and FM fibroblasts.}

Repeated UV exposure can lead to DNA damage and the development of skin cancer. We confirmed that UV induces DNA damage in SF cultures from both FM individuals (Group 2 and 3) and normal controls (Group 1) using $\gamma \mathrm{H} 2 \mathrm{Ax}$ immunofluorescence as a measure of double-stranded DNA breaks. As shown in Figure 5, after 40 seconds of UV exposure, $75-80 \%$ of the SFs had DNA strand breaks. This is consistent with previous studies showing that SF cultures from individuals with an autosomal dominant colon cancer syndrome are not abnormally sensitive to DNA damaging agents such as UV radiation [19].

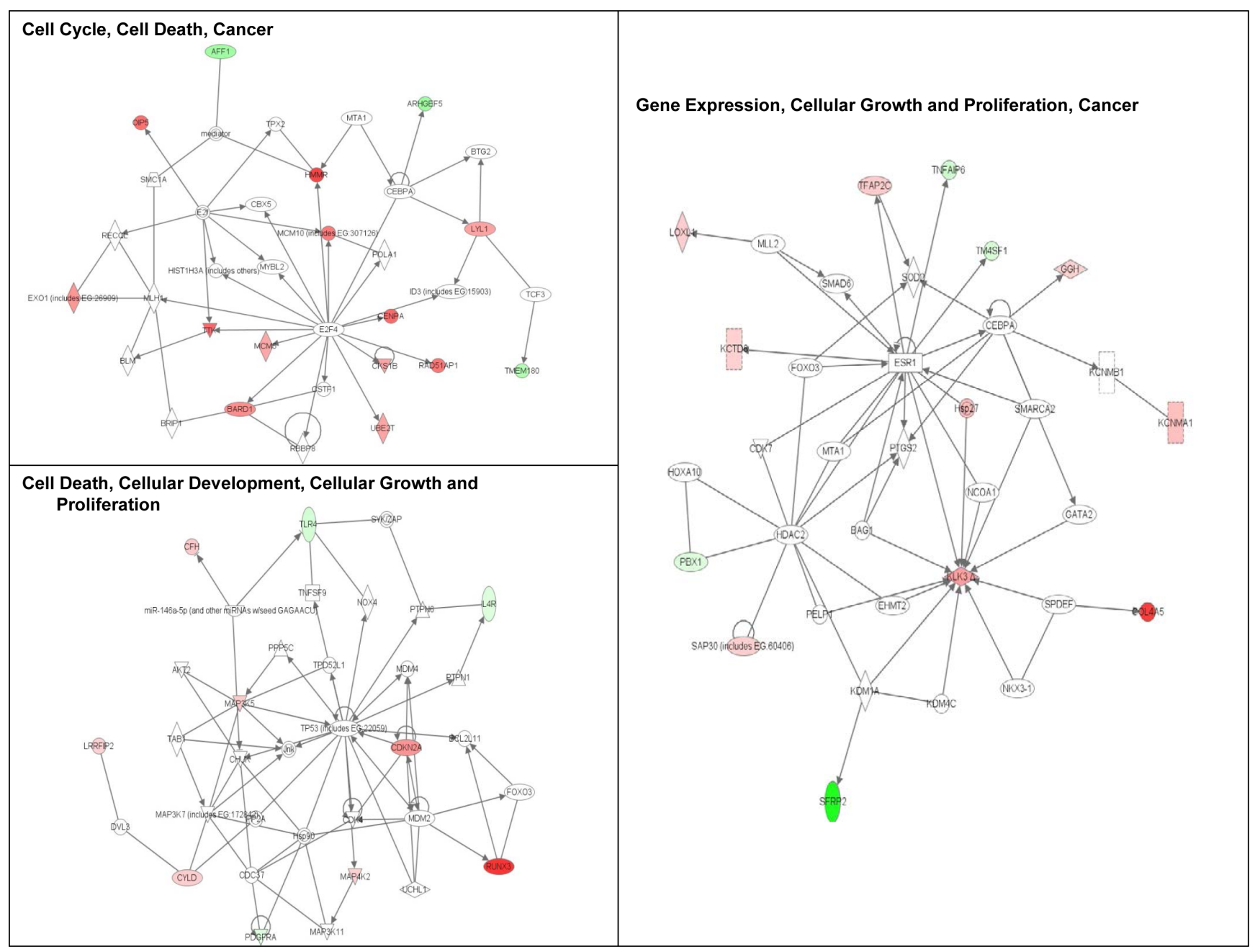

Figure 3: Signaling networks affected by the V126D-p16 mutation. Networks of differentially-expressed genes at baseline in familial SFs with the V126D-p16 mutation (Group 2) were generated using Ingenuity Pathway Analysis software. Genes upregulated or downregulated in Group 2 (vs. Group 1) were highlighted in red or green, respectively. 


\section{Altered gene expression induced by UV-exposure of FM fibroblasts.}

Next we determined the effect of UV exposure on gene expression in SF cultures from normal and FM individuals (Supplementary Table 2). The gene expression distribution clusters among the three groups following UV irradiation (Figure 6) was similar to that seen before UV irradiation (Figure 1). Figure 7 shows pair-wise comparison analysis of UV-irradiated vs. un-irradiated gene expression for each group (one-side $\mathrm{FDR}=0.1$, fold change $\geq 1.5$ ). UV irradiation of normal SF cultures led to the upregulation of 92 genes and downregulation of 85 genes. Expression of 22 and 97 genes was downregulated by UV in Group 2 and 3, respectively, and expression of 14 and 107 genes was upregulated in Group 2 and 3, respectively. However, expression of only a few genes was coordinately regulated between FM and normal SF cultures. In Groups 1 and 2 only PORCN, CHRNB1 and EEF1A1P9 were coordinately downregulated by UV, while the expression of only one gene (CARD10) was coordinately upregulated by UV (Figure 7A). In contrast, there were no genes coordinately upregulated or downregulated by UV in Groups 1 and 3 (Figure 7B). Moreover, there was no overlap of UV-responsive genes between the two groups of SFs with the different CDKN2A mutations.

We then performed an IPA analysis of the genes regulated by UV. Genes associated with cell cycle regulation were over-represented in UV-affected genes in both Group 2 and Group 3 SF cultures (Table 2; Figures 8 and 9). As shown in Figure 8, some of the genes specifically altered in Group 2 are associated with cell death, growth and proliferation as well as tumor morphology. Some of the genes specifically altered in Group 3 are associated with regulating the mitotic roles of polo-like kinases and G2/M damage checkpoints as well as with DNA repair and cancer (Figure 9). Interestingly, cell cycle regulatory pathways are overrepresented in both UV-treated Group 2 and 3 cultures, even though the overall gene expression profile at baseline in Group $2 \mathrm{SF}$ is similar to control Group 1. In contrast to FM mutation carriers, and perhaps, most importantly, the expression of

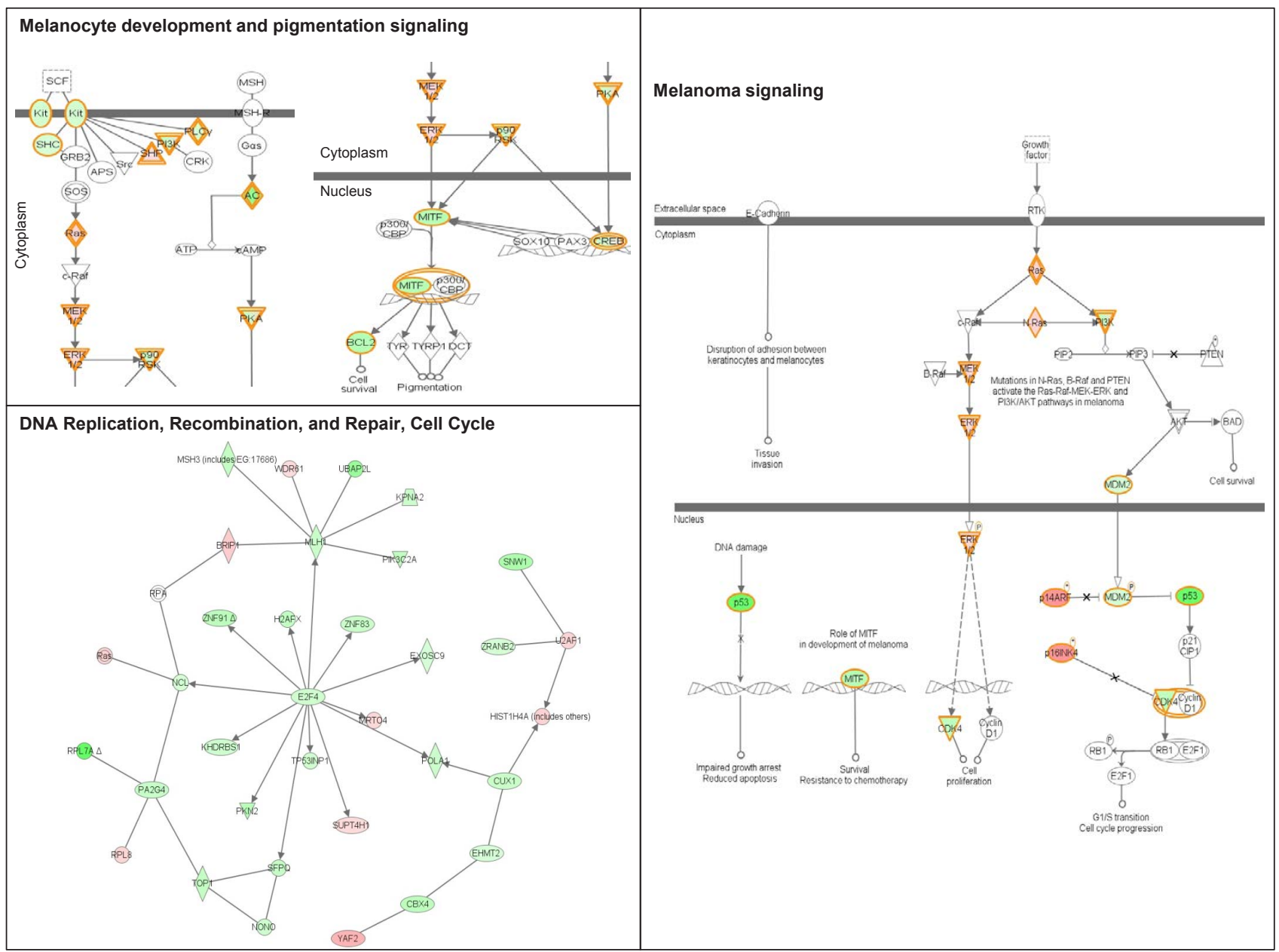

Figure 4: Signaling networks affected by the R87P-p16 mutation. Networks of differentially-expressed genes altered at baseline in familial SFs with a R87P-p16 mutation (Group 3) were generated using Ingenuity Pathway Analysis software. Genes upregulated or downregulated in Group 3 (vs. Group 1) were highlighted in red or green, respectively. 
genes associated with cell cycle regulation was not altered after UV-irradiation of SF from normal controls (Group 1).

To further determine the biological significance of our findings, we compared UV-treated, differentially expressed gene sets in FM fibroblasts with published datasets that account for melanoma development. Thus, genes upregulated in melanoma (Omnibus datasets GDS1375 and GDS1989), were also found to be enriched in UV-upregulated genes of Group 3 SF cultures (Fisher's exact one-tailed $\mathrm{P}$ value $=0.0158$ ). Similarly, genes downregulated in melanoma were found to be enriched in UV-downregulated genes of Group 3 SF cultures (Fisher's exact one-tailed $\mathrm{P}$ value $=0.0043$ ). These differences were not seen in the case of SF from group 2 vs. melanoma. An IPA analysis showed that genes coordinately regulated by UV in Group 3 (UV vs. untreated) SF cultures and in melanoma (vs. normal skin) are involved in cell cycle regulation and apoptosis (Table 2). We therefore validated that the gene expression of AURKA, CCNB1 and CDKN3 was upregulated upon UV-irradiation of Group 3 FM SF cultures (Figure 10A) and compared the expression of these genes in normal skin and melanoma tissue (Figure
10B). As shown in Figure 10B the expression of AURKA, CCNB1 and CDKN3 was enhanced in melanoma tissue as compared to their expression in normal donor skin. In addition, the expression of AFF1, PIM1, PTPN13 and TXNIP was downregulated in UV-irradiated FM SFs with a R87P-CDKN2A mutation (Figure 10A), and the expression of these genes was also found to be downregulated in melanoma tissue (Figure 10B).

\section{DISCUSSION}

Alterations in gene expression associated with single-hit mutations of tumor suppressor genes in phenotypically normal cells appear to represent the earliest molecular changes during cancer development. Previous studies showed that the altered transcriptome and proteome signatures of phenotypically normal cells bearing these single inherited hits parallel many changes observed in the corresponding form of cancer (for review see [17]). Thus, identification of these early alterations may help identify critical molecular targets in both the inherited and sporadic cancers.

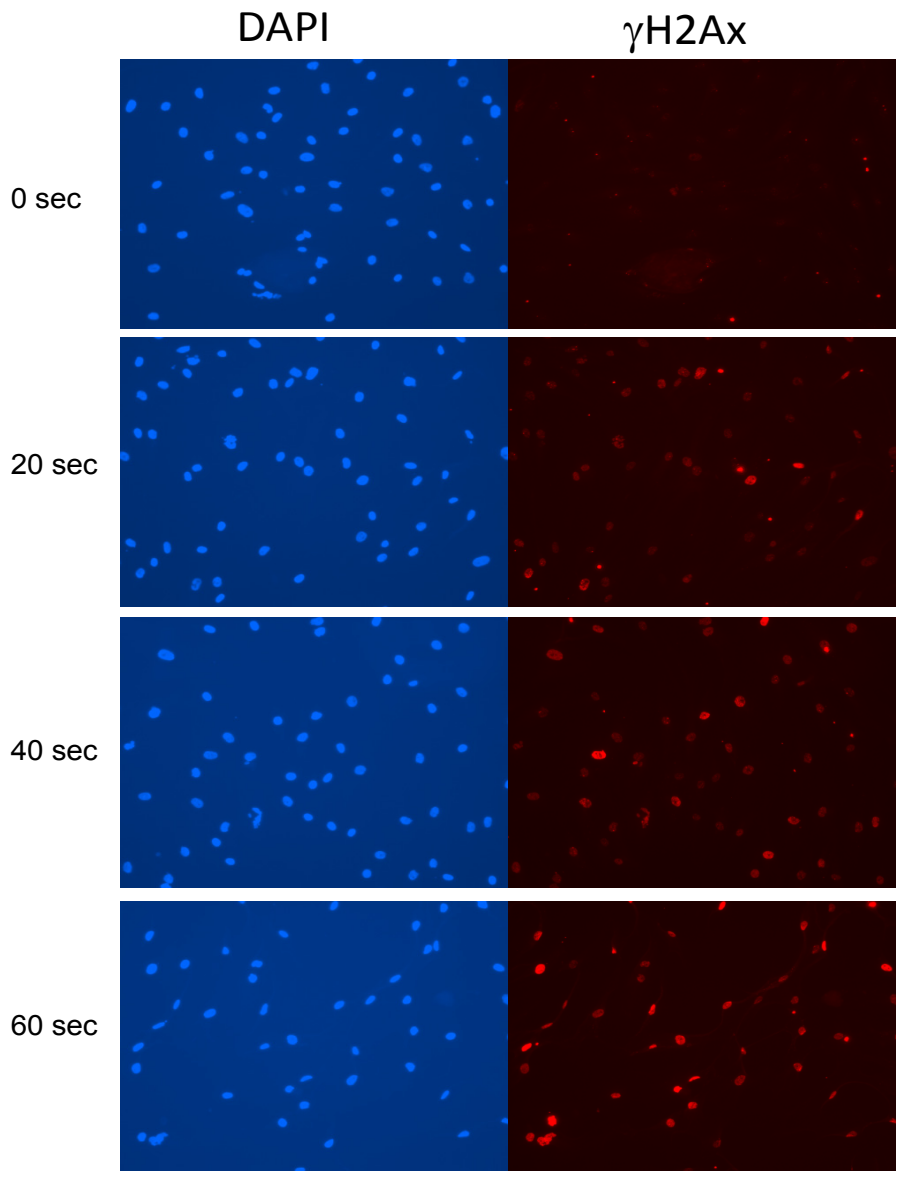

N1
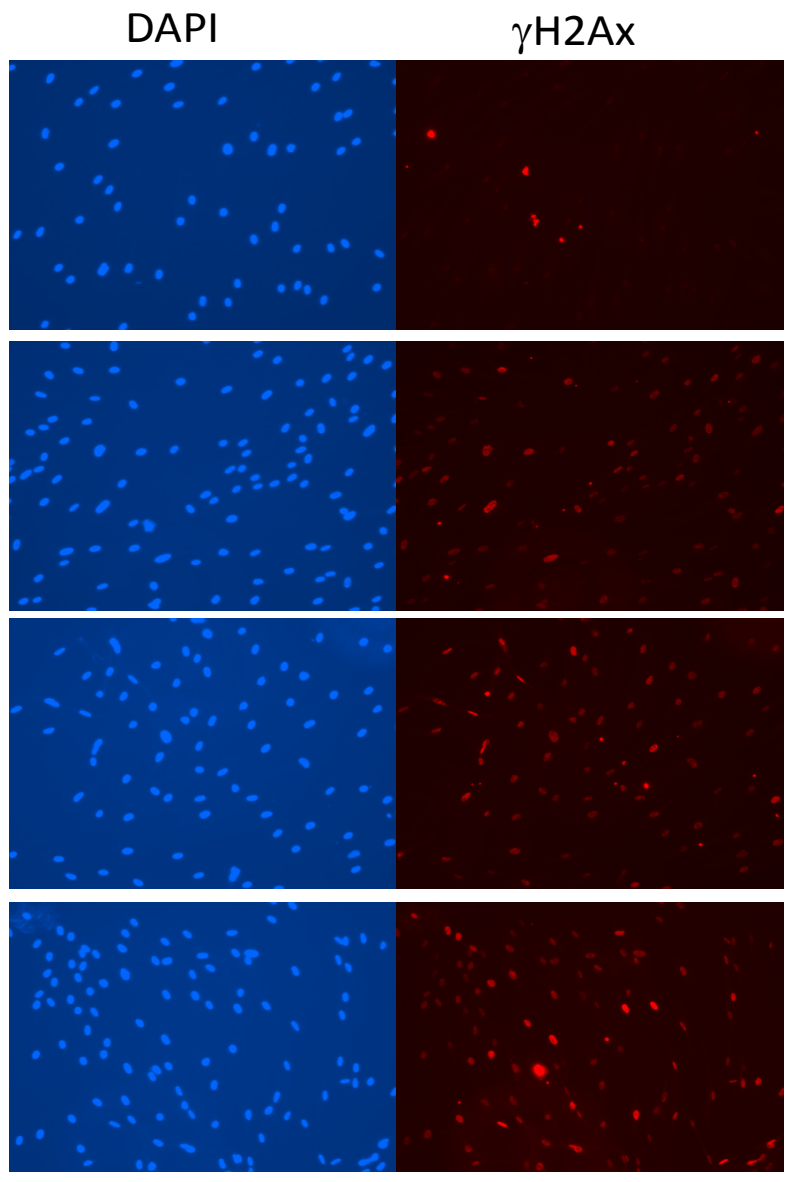

F4

Figure 5: Induction of DNA damage by UV irradiation in SF cultures. SFs from a familial individual (F4) and a normal control individual (N1) were UV-irradiated for 20, 40 or 60 seconds, and then fixed in 3.7\% formaldehyde at 2 hr after UV exposure. Doublestranded DNA breaks were visualized by $\gamma \mathrm{H} 2 \mathrm{Ax}$ immunofluorescence and nuclei were counterstained with DAPI. 
In the present study we compared global gene expression profiles of normal SF from control individuals and phenotypically normal skin-derived fibroblasts from FM individuals with two different CDKN2A/p16 mutations. We examined differences in gene expression profile at baseline and following UV irradiation, leading to the following important findings.

First, the transcriptome signatures are altered by single hit CDK2NA/p16 mutations in phenotypically normal SF from FM families. The extent of altered gene expression is mutation-site specific, with R87Pp16-CDKN2A mutation being far more disruptive than V126D-p16 mutations. This is in agreement with previous studies showing that the R87P-p16 mutation appears to have a more severe phenotype in vitro. The R87P-p16 mutation is an inactivating mutation of CDK4/6 binding [15], inhibits kinase activity [20], results in the accumulation of G1 phase cells [20], and has a predominantly nuclear localization [21]. In contrast, results on the V126D-p16 mutation have been less clear, which may reflect its temperature-sensitive biological effects in vitro and ability to partially "retain" wild type CDK4/6 inhibition [15].

Second, the differentially expressed genes at baseline in R87P-p16 mutation carriers exhibit changes in canonical signaling pathways associated with normal melanocyte development and melanomas. KIT and its downstream effector MITF are part of the canonical signaling pathway involved in melanocyte development and pigmentation. KIT signals via MAPK to activate MITF, which in turn is a potent transcriptional and lineage specific regulator of the three major melanocyte pigment enzymes: tyrosinase, TRP1/TyrpI and TRP2/Dct [22].

A third important finding is that UV-irradiated SF
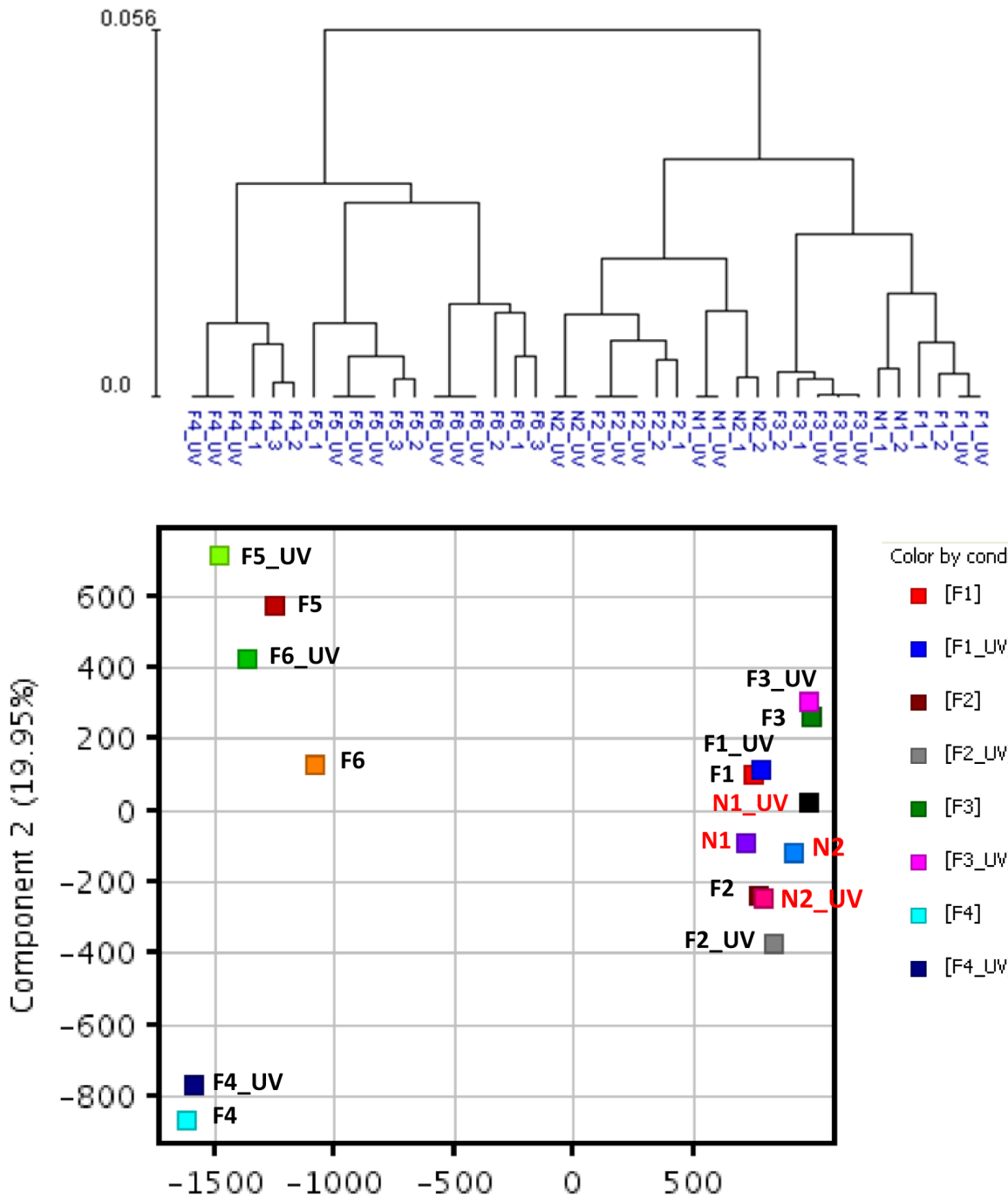

\begin{tabular}{|c|c|}
\hline \multicolumn{2}{|l|}{ Color by conditions } \\
\hline 口 $[\mathrm{F} 1]$ & [ $[\mathrm{F} 5]$ \\
\hline 口 [F1_LW] & $\square\left[\mathrm{F} 5 \_\mathrm{LW}\right]$ \\
\hline [F2] & $\square[\mathrm{F} 6]$ \\
\hline$\square$ [F2_LW] & $\square\left[\mathrm{F} 6 \_\mathrm{L} W\right]$ \\
\hline 口[F3] & 口 [N1] \\
\hline$\square\left[\mathrm{F} 3 \_\mathrm{LW}\right]$ & a [N1_UV] \\
\hline$\square[\mathrm{F} 4]$ & $\square[\mathrm{N} 2]$ \\
\hline D [F4_UV] & $\square$ [N2_UV'] \\
\hline
\end{tabular}

Figure 6: Hierarchical clustering and principal component analysis of gene expression data from SF cultures before and after UV irradiation. Unsupervised hierarchical clustering (upper panel) and principal component analysis (lower panel) were performed on gene expression data from un-irradiated and UV-irradiated SF cultures from the three cohorts using normalized expression data of all probes. 
from FM patients show deregulation of cell cycle and DNA damage response pathways that are diametrically opposite to the gene expression pattern seen following irradiation of fibroblasts from normal controls. For example, cell cycle related genes were downregulated in UV-irradiated fibroblasts from normal individuals, but these genes were upregulated in fibroblasts derived from FM individuals. Moreover, many of the changes in gene expression seen after UV-irradiation of fibroblasts derived from FM individuals are shared with a previously described Gene Expression Omnibus data set of genes deregulated in malignant melanomas, but not in benign nevi [14, 23]. For example, the protein tyrosine phosphatase PTPN13 has been proposed to function as a tumor suppressor; this is in line with its downregulation [24]. In addition, AFF1 is coordinately downregulated in UV-irradiated fibroblasts and in melanoma, and is often dysregulated in cancer [25].

A fourth important observation is that occurrence of the more "benign" V126D-p16 mutation or of the more "disruptive" R87P-p16 mutation within a given FM family is mutually exclusive, supporting the notion that personalized, cohort-based, intervention modalities, including clinical outcome should be adjusted accordingly. We posit that, direct or up/down-stream "pharmacologic normalization" of the R87P-p16 mutation, individually and together with BRAF intervention [26], may enable more effective strategies to delay or even prevent FM, including the occurrence of melanoma in individuals who
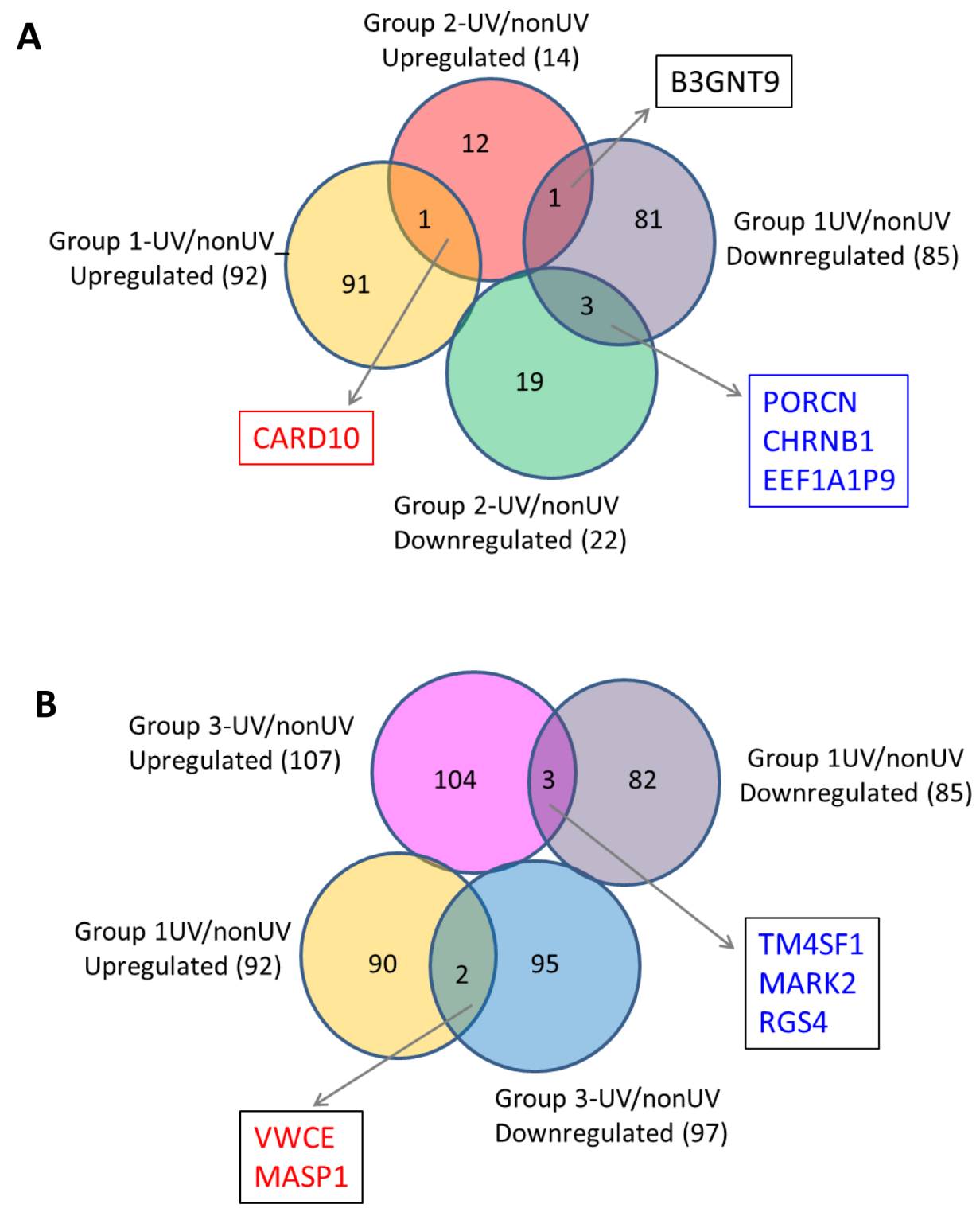

Figure 7: UV-affected genes in normal SFs and familial SFs with distinct CDKN2A mutations. Panel A. Venn diagrams of the UV-affected genes in normal SFs (Group 1) and familial SFs with a V126D-p16 mutation (Group 2). Four genes were coordinately regulated by UV irradiation (3 downregulated and 1 upregulated) in the two groups of SF cultures. Panel B. Venn diagrams of the UVaffected genes in normal SFs (Group 1) and familial SFs with a R87P-p16 mutation (Group 3). Five genes were oppositely regulated by UV irradiation in these two groups of SF cultures. 


\section{TABLE 2: Enriched Ingenuity Function Groups and Signaling Pathways of UV-regulated genes}

\begin{tabular}{|c|c|c|c|c|}
\hline \multicolumn{5}{|c|}{ Enriched Ingenuity Function Groups (Group1-UV vs nonUV) } \\
\hline Functions Annotation & p-Value & & Molecules & \# Molecules \\
\hline cancer & $1.69 \mathrm{E}-02$ & & $\begin{array}{l}\text { ADRA1B,AMPH,BTG1,CFB,CGB,CHRNB1,CLEC11A, } \\
\text { CLEC3B,COLEC12,CSMD1,DAPK1,DUSP1,ECE2,F8,F } \\
\text { CGR2A,FUCA1,GLI2,IFI27,IFT57,IGF2BP3,KCNJ8,KIT } \\
\text {,KRT7,LGR4,LMO2,MASP1,MLPH,NDRG1,NPTX1,NR } \\
\text { 3C1,PHGDH,PRRX1,RASSF4,RGS4,ROBO1,RUNDC3B, } \\
\text { SATB1,SEL1L,SEMA3C,SERPING1,SOCS2,STON1,TFA } \\
\text { P2A,TGFBR3,TM4SF1,ZFPM2 }\end{array}$ & 46 \\
\hline metastasis & $2.78 \mathrm{E}-02$ & & COLEC12,LGR4,MLPH,PRRX1,RGS4,TGFBR3,TM4SF1 & 7 \\
\hline \multicolumn{5}{|c|}{ Enriched Ingenuity Function Groups (Group2-UV vs nonUV) } \\
\hline Functions Annotation & p-Value & & Molecules & \# Molecules \\
\hline proliferation of tumor cell lines & $3.87 \mathrm{E}-02$ & & ATF3,BAK1,CARD10,CDK11A/CDK11B,FLT3LG,PTMA & 6 \\
\hline cell cycle progression & $9.05 \mathrm{E}-03$ & & ATF3,CARD10,FLT3LG,IL12A,PTMA & 5 \\
\hline \multicolumn{5}{|c|}{ Enriched Ingenuity Function Groups (Group3-UV vs nonUV) } \\
\hline Functions Annotation & p-Value & $\begin{array}{l}\text { Activation } \\
\text { z-score }\end{array}$ & Molecules & \# Molecules \\
\hline metastasis & $1.31 \mathrm{E}-04$ & & $\begin{array}{l}\text { ANGPTL2,C10orf116,DLGAP5,EPHA2,IGFBP5,MME,M } \\
\text { MP3,PAPPA,RGS4,SEL1L3,TM4SF1,TXNIP,VEGFA }\end{array}$ & 13 \\
\hline tumorigenesis & $1.37 \mathrm{E}-08$ & 0.832 & $\begin{array}{l}\text { ADAMTS5,AFP,ANGPTL2,APOD,ASF1B,AURKA,BAR } \\
\text { D1,BIRC5,BUB1,C10orf116,CACNA1C,CASD1,CCNB1, } \\
\text { CCNB2,CDC20,CDCA8,CDKN3,CENPA,CKS1B,COL7A } \\
\text { 1,CRIP1,DEPDC1,DLGAP5,DUSP2,ENPP1,EPHA2,EXO } \\
\text { 1,FAM83D,FBLN5,FUBP1,GBP2,GTF2I,HMMR,HSPB7 } \\
\text {,IGFBP5,ISOC1,ITGB3,KIF11,KIF14,KIF23,KIF2C,MA } \\
\text { SP1,MCM10,MCM5,MME,MMP12,MMP3,MXI1,NEK2 } \\
\text {,OSR2,PAPPA,PAQR4,PDE5A,PDPN,PHLDA2,PIM1,PL } \\
\text { K1,PLK4,PLXNC1,PRDM1,PRSS12,PTGER2,RACGAP } \\
\text { 1,RGS2,RGS4,RNASEH2A,RREB1,SCG2,SCP2,SEL1L } \\
\text { 3,SFRP1,SLC47A1,SMOX,TM4SF1,TTK,TXNIP,UBE2T } \\
\text {,VEGFA,VHL,VRK1,VWA5A,WISP2 }\end{array}$ & 82 \\
\hline angiogenesis & $6.48 \mathrm{E}-03$ & -0.595 & $\begin{array}{l}\text { ANGPTL2,GTF2I,ITGB3,MMP12,RGS4,RHOJ,SCG2,V } \\
\text { EGFA }\end{array}$ & 8 \\
\hline Cell Cycle, arrest in G2 phase & $8.56 \mathrm{E}-03$ & & AURKA,CCNB1,IGFBP5,MXI1,PLK1 & 5 \\
\hline Cell Cycle, arrest in M phase & $3.41 \mathrm{E}-03$ & & CDC20,NUF2,PLK1 & 3 \\
\hline Cell Cycle, arrest in mitosis & 7.82E-04 & & BIRC5,BUB1,PLK1,TTK & 4 \\
\hline Cell Cycle, cell cycle progression & 6.91E-08 & -2.71 & $\begin{array}{l}\text { AURKA,BIRC5,BORA,BUB1,CCNB1,CDC20,CDCA8,C } \\
\text { DKN3,CENPA,DLGAP5,IGFBP5,KIF11,KIF2C,MXI1,ND } \\
\text { C80,NEK2,NUDT1,NUF2,PIM1,PLK1,SKA1,SKA3,TM4 } \\
\text { SF1,TTK,VEGFA,VHL }\end{array}$ & 26 \\
\hline Cell Cycle, checkpoint control & $1.52 \mathrm{E}-02$ & & BUB1,CDC20,NDC 80 & 3 \\
\hline Cell Cycle, cleavage of cells & $1.89 \mathrm{E}-02$ & & BIRC5,FUBP1,SKA1 & 3 \\
\hline Cell Cycle, cytokinesis & $1.40 \mathrm{E}-07$ & 2.157 & $\begin{array}{l}\text { AURKA,BIRC5,CCNB1,CDC20,KIF14,KIF23,PIM1,PLK } \\
\text { 1,RACGAP1,TM4SF1 } \\
\end{array}$ & 10 \\
\hline $\begin{array}{l}\text { Cell Cycle, delay in initiation of } \mathrm{M} \\
\text { phase }\end{array}$ & $1.96 \mathrm{E}-05$ & -0.152 & BIRC5,CCNB1,PIM1,PLK1 & 4 \\
\hline Cell Cycle, G2/M phase & $3.34 \mathrm{E}-03$ & & AURKA,BIRC5,CCNB1,IGFBP5,MXI1,PLK1 & 6 \\
\hline Cell Cycle, interphase & $2.66 \mathrm{E}-02$ & & $\begin{array}{l}\text { AURKA,BIRC5,CCNB1,CDKN3,IGFBP5,MCM10,MXI1 } \\
\text {,PIM1,PLK1,TXNIP,VHL }\end{array}$ & 11 \\
\hline Cell Cycle, M phase & $6.50 \mathrm{E}-11$ & 1.803 & $\begin{array}{l}\text { AURKA,BIRC5,CCNB1,CDC20,CDCA8,DLGAP5,KIF1 } \\
\text { 4,KIF23,LRRC6,NUF2,PIM1,PLK1,RACGAP1,SKA1,T } \\
\text { M4SF1 }\end{array}$ & 15 \\
\hline
\end{tabular}




\begin{tabular}{|c|c|c|c|c|}
\hline Cell Cycle, mitosis & $5.16 \mathrm{E}-11$ & -1.769 & $\begin{array}{l}\text { AURKA,BIRC5,BORA,BUB1,CCNB1,CDC20,CDCA8, } \\
\text { CENPA,DLGAP5,IGFBP5,KIF11,KIF2C,NDC80,NEK2, } \\
\text { NUF2,PLK1,SKA1,SKA3,TTK,VEGFA }\end{array}$ & 20 \\
\hline Cell Cycle, senescence of cells & $4.08 \mathrm{E}-03$ & -1.467 & BUB1,CENPA,NUDT1,TM4SF1,VEGFA & 5 \\
\hline $\begin{array}{l}\text { Cell Cycle, spindle checkpoint of } \\
\text { cells }\end{array}$ & $1.33 \mathrm{E}-06$ & & BIRC5,BUB1,DLGAP5,PLK1,TTK & 5 \\
\hline cell death & $1.98 \mathrm{E}-02$ & -0.295 & $\begin{array}{l}\text { AFP,AURKA,BARD1,BIRC5,CCNB1,CDC20,DEPDC1, } \\
\text { EPHA2,FUBP1,HMMR,IGFBP5,IL17D,ITGB3,ITGB3B } \\
\text { P,KIF11,KIF14,MCM10,MME,NDC80,NDP,NEK2,NFK } \\
\text { BIZ,NUAK2,NUF2,PHLDA2,PIM1,PLK1,PRDM1,PTP } \\
\text { N13,RGS4,RIPK3,SCG2,SFRP1,SLC47A1,SMOX,TTK } \\
\text {,VEGFA,VHL }\end{array}$ & 38 \\
\hline differentiation of cells & $5.88 \mathrm{E}-03$ & -0.678 & $\begin{array}{l}\text { ANGPTL2,BHLHE41,ENPP1,IGFBP5,IL17D,ITGB3,P } \\
\text { DE5A,PRDM1,PRKX,RACGAP1,RGS4,SFRP1,TXNIP, } \\
\text { VEGFA,VHL }\end{array}$ & 15 \\
\hline proliferation of cells & $5.81 \mathrm{E}-05$ & 1.245 & \begin{tabular}{|l|} 
AFF1,AFP,APOD,AURKA,BARD1,BIRC5,BUB1,CDC \\
A8,CDKN3,CKS1B,CRIP1,DLGAP5,ENPP1,EPHA2,ER \\
BB2IP,FABP3,HMMR,IGFBP5,ITGB3,KCNN4,KIF11,K \\
IF2C,LEPREL1,MCM5,MMP12,MXI1,NDP,NEK2,NFA \\
TC4,NUDT1,PDE5A,PENK,PHLDA2,PIM1,PLK1,PRD \\
M1,PTGER2,PTPN13,RACGAP1,RGS4,SCG2,SFRP1,S \\
MOX,STEAP2,TTK,TXNIP,UTP20,VEGFA,VHL,WISP2
\end{tabular} & 50 \\
\hline invasion of cells & $7.58 \mathrm{E}-03$ & -0.187 & $\begin{array}{l}\text { AURKA,EPHA2,FBLN5,HMMR,ITGB3,MMP3,NUAK2 } \\
\text {,PAPPA,PTGER2,RGS4,SFRP1,VEGFA,VHL }\end{array}$ & 13 \\
\hline DNA damage & $9.86 \mathrm{E}-03$ & -1.922 & BIRC5,MCM10,PLK1,SMOX & 4 \\
\hline \multicolumn{5}{|c|}{ Enriched Ingenuity Canonical pathways (Group3-UV vs nonUV) } \\
\hline Ingenuity Canonical Pathways & \begin{tabular}{|l|}
$-\log (\mathrm{p}-$ \\
value $)$
\end{tabular} & Ratio & Molecules & \\
\hline \begin{tabular}{|l|} 
Mitotic Roles of Polo-Like Kinase \\
\end{tabular} & $5.22 \mathrm{E}+00$ & $1.09 \mathrm{E}-01$ & KIF23,PLK4,CDC20,CCNB2,PLK1,KIF11,CCNB1 & \\
\hline $\begin{array}{l}\text { Cell Cycle: G2/M DNA Damage } \\
\text { Checkpoint Regulation }\end{array}$ & $2.86 \mathrm{E}+00$ & $8.33 \mathrm{E}-02$ & CKS1B,CCNB2,PLK1,CCNB1 & \\
\hline HIF1A Signaling & $1.57 \mathrm{E}+00$ & $3.92 \mathrm{E}-02$ & VEGFA,MMP3,MMP12,VHL & \\
\hline cAMP-mediated signaling & $1.48 \mathrm{E}+00$ & $2.82 \mathrm{E}-02$ & RGS2,NPR3,ADCY4,RGS4,PDE5A,PTGER2 & \\
\hline \multicolumn{5}{|c|}{ Enriched Ingenuity Function Groups (Overlap_Group3-UV vs nonUV and Melanoma vs normal skin) } \\
\hline Functions Annotation & p-Value & $\begin{array}{l}\text { Activation } \\
\text { z-score }\end{array}$ & Molecules & \# Molecules \\
\hline proliferation of cells & $8.79 \mathrm{E}-04$ & 1.247 & $\begin{array}{l}\text { AFF1,APOD,AURKA,BIRC5,BUB1,CDKN3,DLGAP5, } \\
\text { ENPP1,HMMR,KIF2C,PHLDA2,PIM1,PLK1,PTPN13,S } \\
\text { CG2,TTK,TXNIP }\end{array}$ & 17 \\
\hline cell death & 2.04E-04 & -1.034 & $\begin{array}{l}\text { AURKA,BIRC5,CCNB1,CDC20,DEPDC1,HMMR,IL17 } \\
\text { D,KIF14,NDC80,NUF2,PHLDA2,PIM1,PLK1,PTPN13, } \\
\text { SCG2,TTK }\end{array}$ & 16 \\
\hline cell cycle progression & 6.97E-08 & -1.916 & \begin{tabular}{|l|} 
AURKA,BIRC5,BUB1,CCNB1,CDC20,CDKN3,DLGAP \\
5,KIF2C,NDC80,NUF2,PIM1,PLK1,TTK
\end{tabular} & 13 \\
\hline \multicolumn{5}{|c|}{ Enriched Ingenuity Canonical Groups (Overlap_Group3-UV vs nonUV and Melanoma vs normal skin) } \\
\hline Ingenuity Canonical Pathways & \begin{tabular}{|c|}
$-\log (\mathrm{p}-$ \\
value $)$
\end{tabular} & Ratio & Molecules & \\
\hline Mitotic Roles of Polo-Like Kinase & $4.57 \mathrm{E}+00$ & $6.25 \mathrm{E}-02$ & CDC20,CCNB2,PLK1,CCNB1 & \\
\hline $\begin{array}{l}\text { Cell Cycle: G2/M DNA Damage } \\
\text { Checkpoint Regulation }\end{array}$ & $3.56 \mathrm{E}+00$ & $6.25 \mathrm{E}-02$ & CCNB2,PLK1,CCNB1 & \\
\hline
\end{tabular}

are otherwise at risk. In this regard, proclivity towards pancreatic cancer that is likely to be caused by CDKN2A mutations [6-8], particularly among affected carriers of the R87P-p16 mutation, should be explored for early diagnosis/prognosis and intervention of pancreatic cancer.
Together, these data suggest that genomic profiling of phenotypically normal SF can help identify novel molecular targets for chemoprevention, including early specific biomarkers of melanoma risk among individuals who are heterozygous for CDKN2A mutations within 
Cell Death, Tumor Morphology, Cellular Growth and Proliferation

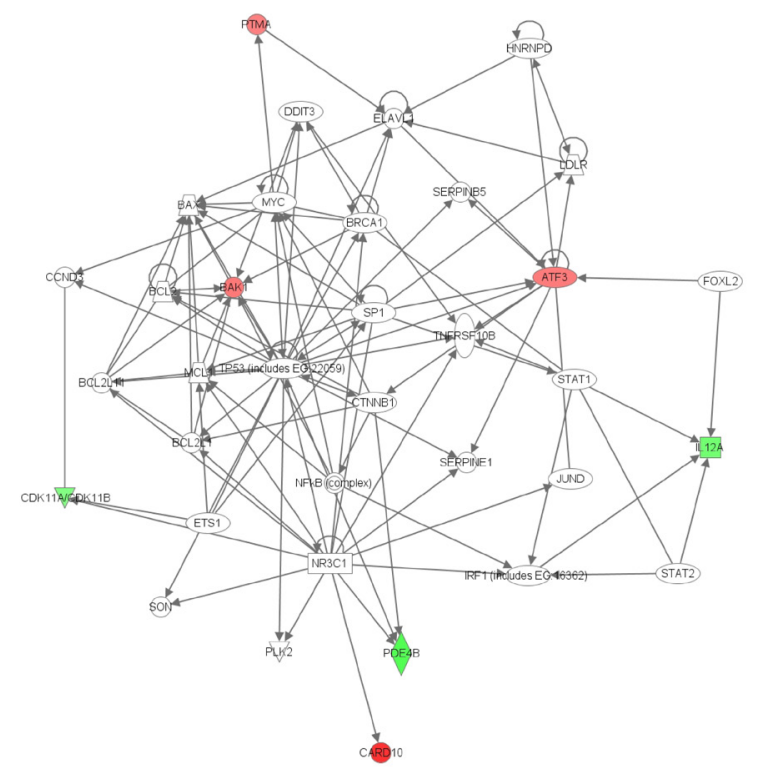

Figure 8: Signaling network of genes affected by UV in familial SFs with a V126D-p16 mutation. The gene network was generated using Ingenuity Pathway Analysis software. Genes upregulated or downregulated by UV in Group 2 were highlighted in red or green, respectively.
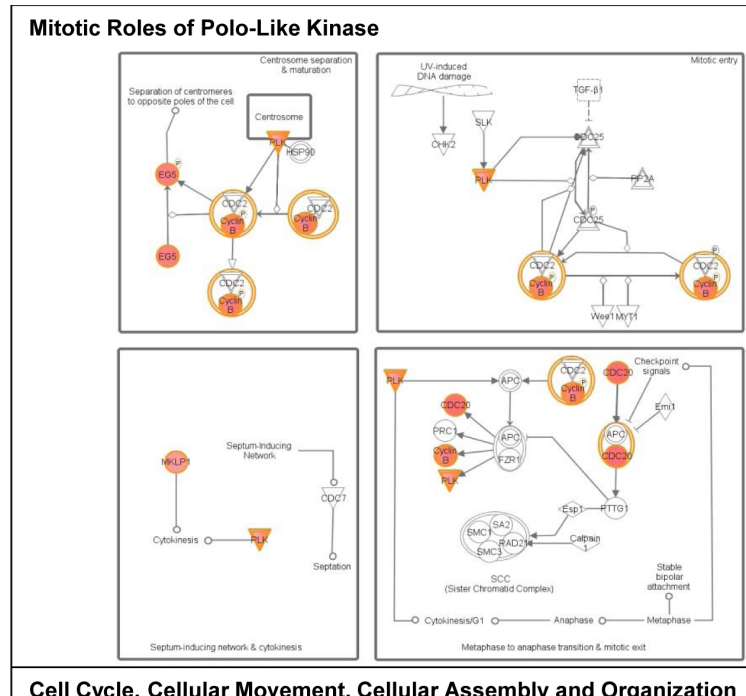

Cell Cycle, Cellular Movement, Cellular Assembly and Organization

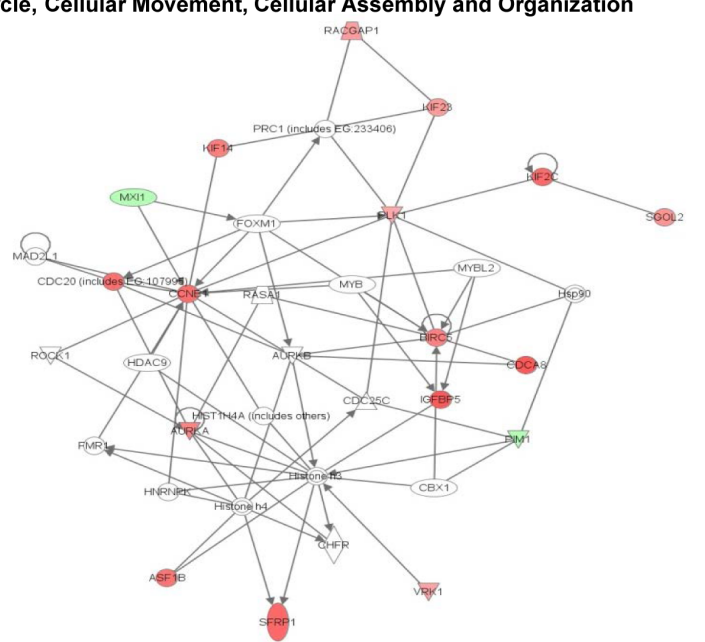

Cell Cycle: G2/M DNA Damage Checkpoint Regulation

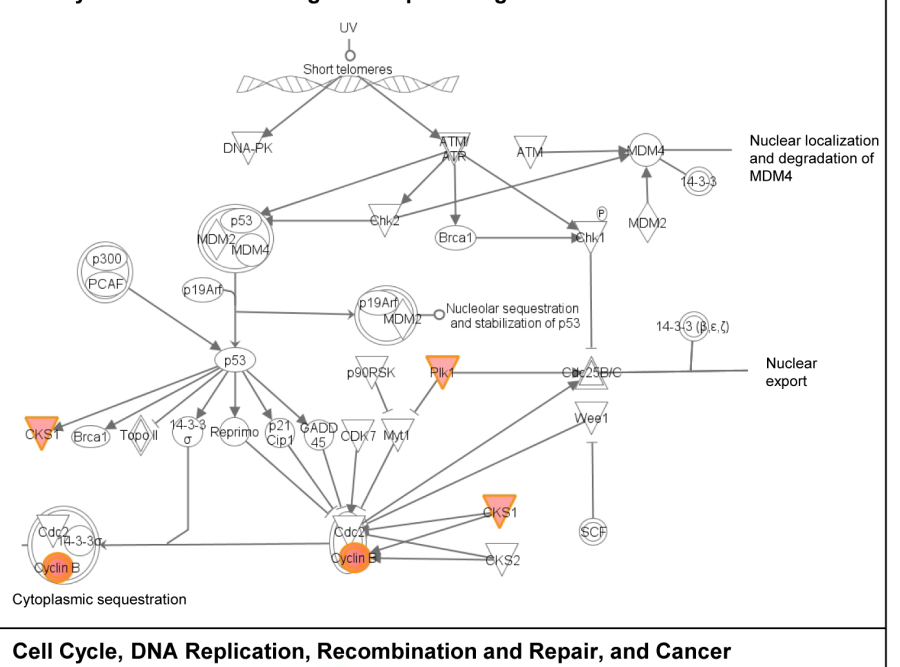

Cell Cycle, DNA Replication, Recombination and Repair, and Cancer

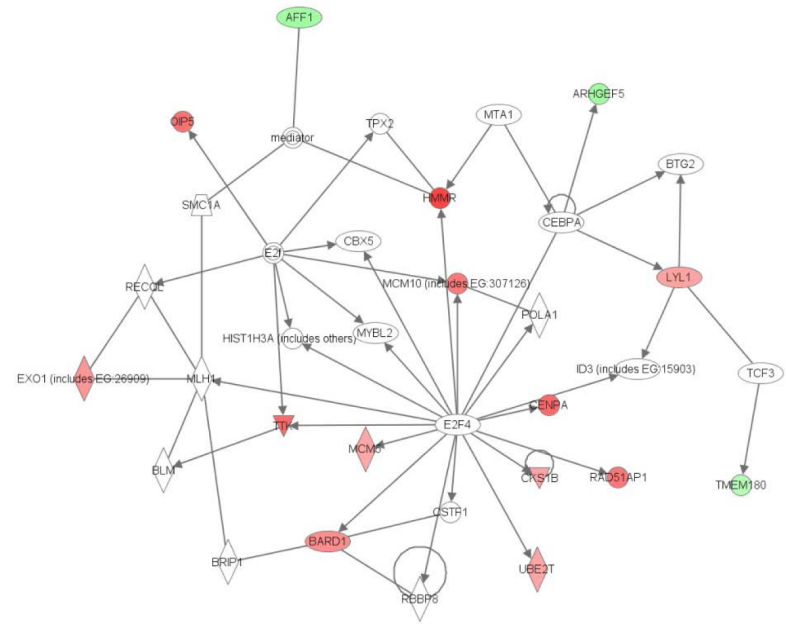

Figure 9: Signaling networks affected by UV in familial SFs with a R87P-p16 mutation. The gene networks were generated using Ingenuity Pathway Analysis software. Genes upregulated or downregulated by UV in Group 3 were highlighted in red or green, respectively. 
FM families; these potential biomarkers would enable mechanism-based early detection of melanoma and personalized prevention strategies to target sporadic melanoma.

A

B
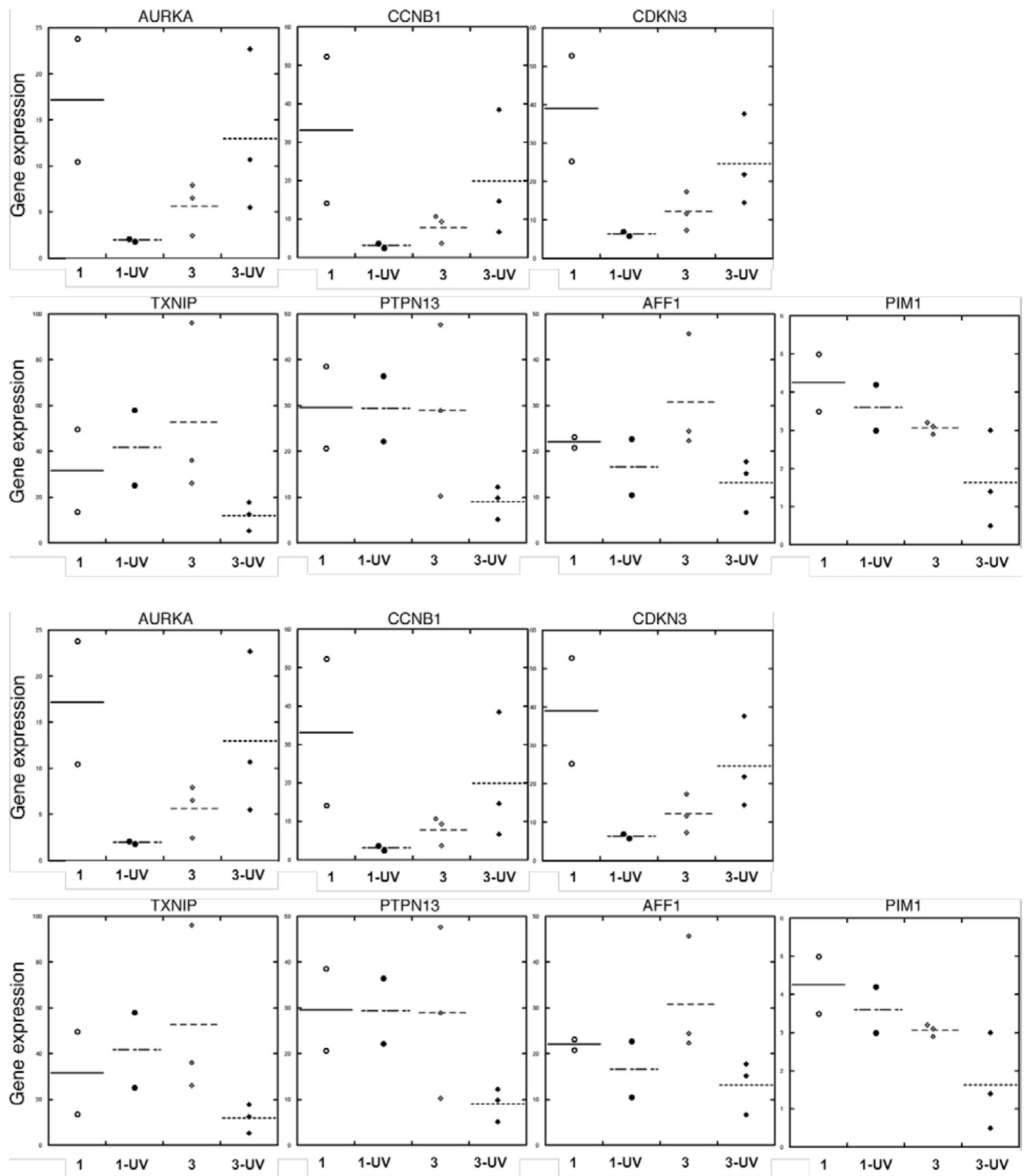

Figure 10: Expression in normal skin and melanoma tissue of genes affected by UV in familial SFs with a R87P-p16 mutation. RNA was isolated from (Panel A) unirradiated and UV-irradiated SFs from Group 1 (normal) and Group 3 (a R87P-p16 mutation), or (Panel B) normal skin and melanoma tissue, and mRNA levels of the indicated genes were measured by qPCR, normalized to $\beta$-actin expression, and presented as means. The horizontal line shows the mean value for all members of each group of samples. 
$\mathrm{mg} / \mathrm{ml})$ and fungizone $(250 \mathrm{ng} / \mathrm{ml})$ at $37^{\circ} \mathrm{C}$ with $5 \% \mathrm{CO}_{2}$. Medium was changed every 2-3 days, and cells were passaged at confluence at 1:3.

\section{Microarray Analysis}

Total RNA from three independent experiments was prepared using miRNeasy Mini kit (QIAGEN, Valencia, CA) and submitted to the UTHSC Center of Genomics and Bioinformatics (Memphis, TN) for labeling and hybridization to HT-12 expression BeadChips (Illumina Inc.). RNA integrity was validated on an Agilent bioanalyzer, and all samples showed distinct peaks corresponding to intact $28 \mathrm{~S}$ and $18 \mathrm{~S}$ ribosomal RNA. Hybridization signals were processed using Illumina GenomeStudio software (annotation, background subtraction, Quantile normalization and presence call filtering). The processed data were filtered to exclude probes with detection $p$ value $>0.05$ in more than half of the samples. In addition, the hybridization signal intensities $<40$ were set to the flooring value of 40. GeneSpring GX software (Agilent Technologies) and Expander (Expression Analyzer and Displayer with the $\mathrm{R}$ environment) were used for statistical computing and graphics [27]. SAM (Significance Analysis of Microarray) was used to detect probes that demonstrate differential expression among the different subsets of samples (Group 1, 2 and 3_untreated, n=3; Group 1, 2 and 3_UV irradiated, $\mathrm{n}=3$; each subset contains 2-3 biological duplicates) with one-side $\mathrm{FDR}=0.1$. The differentially expressed genes were subjected to fold change analysis. UV-regulated genes were defined as genes with $\mathrm{FC} \geq 1.5$ (UV treated vs. untreated) and were further subjected to functional annotation and signaling pathway mapping using the Ingenuity Pathway Analysis software (IPA, Ingenuity Systems, Inc.) [28], and clinical relevance analysis using the expression array data of melanoma tissues deposited in Gene Expression Omnibus (GDS1375 and GDS1989).

\section{Quantitative Real time-PCR.}

Quantitative real time-PCR (qPCR) was performed using gene-specific primers (sequences in Table S2) on the iCyclerIQ detection system (BioRad, Hercules, CA) using iScript One-Step RT-PCR Kit with SYBR Green (BioRad) as previously described [29, 30]. Reaction parameters were as follows: cDNA synthesis at $50^{\circ} \mathrm{C}$ for $20 \mathrm{~min}$, iScript reverse transcriptase inactivation at $95^{\circ} \mathrm{C}$ for $5 \mathrm{~min}$, PCR cycling at $95^{\circ} \mathrm{C}$ for $10 \mathrm{sec}$ and $60^{\circ} \mathrm{C}$ for $30 \mathrm{sec}$ for 40 cycles. Gene expression data was normalized to the expression of the $\beta$-actin housekeeping gene. The relative units were calculated from a standard curve, plotting 3 different concentrations against the PCR cycle number at the cycle threshold (with a 10 -fold increment equivalent to $\sim 3.1$ cycles).

\section{UV-irradiation.}

Human SFs were grown on glass coverslips in 6-well plates in DMEM with 20\% FCS and Penicillin/ Streptomycin. Before irradiation the media was aspirated and cells were washed twice with PBS. The coverslips were transferred to a Petri dish containing PBS. The dishes were placed in the UV chamber of a BioRad GS Gene Linker and irradiated with UV light at 2 mJoules/ $\mathrm{cm}^{2}$. Following irradiation the coverslips were transferred to new 6-well plates, fresh media was added and cells were returned to the incubator. Induction of DNA damage by UV irradiation was examined using $\gamma \mathrm{H} 2 \mathrm{Ax}$ immunofluorescence as a measure of double-stranded DNA breaks.

\section{ACKNOWLEDGEMENTS}

This work was supported by National Cancer Institute HHSN261200433000C and by funds from the Muirhead Chair Endowment at the University of Tennessee Health Science Center. We thank Judy Fay for editorial assistance.

\section{REFERENCE}

1. Siegel R, Naishadham D and Jemal A. Cancer statistics, 2012. CA: a cancer journal for clinicians. 2012; 62(1):1029.

2. Narayanan DL, Saladi RN and Fox JL. Ultraviolet radiation and skin cancer. International journal of dermatology. 2010; 49(9):978-986.

3. Tsao H, Chin L, Garraway LA and Fisher DE. Melanoma: from mutations to medicine. Genes Dev. 2012; 26(11):11311155 .

4. Kefford RF, Newton Bishop JA, Bergman W and Tucker MA. Counseling and DNA testing for individuals perceived to be genetically predisposed to melanoma: A consensus statement of the Melanoma Genetics Consortium. J Clin Oncol. 1999; 17(10):3245-3251.

5. Piepkorn M. Melanoma genetics: an update with focus on the CDKN2A(p16)/ARF tumor suppressors. J Am Acad Dermatol. 2000; 42 (5 Pt 1):705-722; quiz 723-706.

6. Lynch HT, Fusaro RM, Lynch JF and Brand R. Pancreatic cancer and the FAMMM syndrome. Familial cancer. 2008; 7(1):103-112.

7. Goldstein AM, Chan M, Harland M, Gillanders EM, Hayward NK, Avril MF, Azizi E, Bianchi-Scarra G, Bishop DT, Bressac-de Paillerets B, Bruno W, Calista D, Cannon Albright LA, Demenais F, Elder DE, Ghiorzo P, et al. High-risk melanoma susceptibility genes and pancreatic cancer, neural system tumors, and uveal melanoma across GenoMEL. Cancer Res. 2006; 66(20):9818-9828.

8. Parker JF, Florell SR, Alexander A, DiSario JA, Shami PJ 
and Leachman SA. Pancreatic carcinoma surveillance in patients with familial melanoma. Archives of dermatology. 2003; 139(8):1019-1025.

9. Qiu W, Sahin F, Iacobuzio-Donahue CA, Garcia-Carracedo D, Wang WM, Kuo CY, Chen D, Arking DE, Lowy AM, Hruban RH, Remotti HE and Su GH. Disruption of p16 and activation of Kras in pancreas increase ductal adenocarcinoma formation and metastasis in vivo. Oncotarget. 2011; 2(11):862-873.

10. Pho L, Grossman D and Leachman SA. Melanoma genetics: a review of genetic factors and clinical phenotypes in familial melanoma. Current opinion in oncology. 2006; 18(2):173-179.

11. Hodis E, Watson IR, Kryukov GV, Arold ST, Imielinski M, Theurillat JP, Nickerson E, Auclair D, Li L, Place C, Dicara D, Ramos AH, Lawrence MS, Cibulskis K, Sivachenko A, Voet $\mathrm{D}$, et al. A landscape of driver mutations in melanoma. Cell. 2012; 150(2):251-263.

12. Stott FJ, Bates S, James MC, McConnell BB, Starborg M, Brookes S, Palmero I, Ryan K, Hara E, Vousden KH and Peters G. The alternative product from the human CDKN2A locus, p14(ARF), participates in a regulatory feedback loop with p53 and MDM2. EMBO J. 1998; 17(17):5001-5014.

13. Bishop DT, Demenais F, Goldstein AM, Bergman W, Bishop JN, Bressac-de Paillerets B, Chompret A, Ghiorzo P, Gruis N, Hansson J, Harland M, Hayward N, Holland EA, Mann GJ, Mantelli M, Nancarrow D, et al. Geographical variation in the penetrance of CDKN2A mutations for melanoma. J Natl Cancer Inst. 2002; 94(12):894-903.

14. Talantov D, Mazumder A, Yu JX, Briggs T, Jiang Y, Backus J, Atkins D and Wang Y. Novel genes associated with malignant melanoma but not benign melanocytic lesions. Clin Cancer Res. 2005; 11(20):7234-7242.

15. Parry D and Peters G. Temperature-sensitive mutants of p16CDKN2 associated with familial melanoma. Mol Cell Biol. 1996; 16(7):3844-3852.

16. Gordon PR, Treloar VD, Vrabel MA and Gilchrest BA. Relative responsiveness of cultured human epidermal melanocytes and melanoma cells to selected mitogens. J Invest Dermatol. 1986; 87(6):723-727.

17. Herbert BS, Chanoux RA, Liu Y, Baenziger PH, Goswami CP, McClintick JN, Edenberg HJ, Pennington RE, Lipkin SM and Kopelovich L. A molecular signature of normal breast epithelial and stromal cells from Li-Fraumeni syndrome mutation carriers. Oncotarget. 2010; 1(6):405422.

18. Leachman SA, Carucci J, Kohlmann W, Banks KC, Asgari MM, Bergman W, Bianchi-Scarra G, Brentnall T, Bressacde Paillerets B, Bruno W, Curiel-Lewandrowski C, de Snoo FA, Debniak T, Demierre MF, Elder D, Goldstein AM, et al. Selection criteria for genetic assessment of patients with familial melanoma. J Am Acad Dermatol. 2009; 61(4):677 e671-614.

19. Kopelovich L. Skin fibroblasts from humans predisposed to colon cancer are not abnormally sensitive to DNA damaging agents. Cell biology international reports. 1983; 7(5):369-375.

20. Koh J, Enders GH, Dynlacht BD and Harlow E. Tumourderived p16 alleles encoding proteins defective in cell-cycle inhibition. Nature. 1995; 375(6531):506-510.

21. Walker GJ, Gabrielli BG, Castellano M and Hayward NK. Functional reassessment of P16 variants using a transfection-based assay. Int J Cancer. 1999; 82(2):305-312.

22. Goding CR. Mitf from neural crest to melanoma: signal transduction and transcription in the melanocyte lineage. Genes Dev. 2000; 14(14):1712-1728.

23. Smith AP, Hoek $\mathrm{K}$ and Becker D. Whole-genome expression profiling of the melanoma progression pathway reveals marked molecular differences between nevi/ melanoma in situ and advanced-stage melanomas. Cancer Biol Ther. 2005; 4(9):1018-1029.

24. Glondu-Lassis M, Dromard M, Lacroix-Triki M, Nirde P, Puech C, Knani D, Chalbos D and Freiss G. PTPL1/ PTPN13 regulates breast cancer cell aggressiveness through direct inactivation of Src kinase. Cancer Res. 2010; 70(12):5116-5126.

25. Tamai H, Miyake K, Yamaguchi H, Takatori M, Dan K, Inokuchi $\mathrm{K}$ and Shimada $\mathrm{T}$. Resistance of MLL-AFF1positive acute lymphoblastic leukemia to tumor necrosis factor-alpha is mediated by S100A6 upregulation. Blood cancer journal. 2011; 1(11):e38.

26. Kumar R, Angelini S and Hemminki K. Activating BRAF and N-Ras mutations in sporadic primary melanomas: an inverse association with allelic loss on chromosome 9. Oncogene. 2003; 22(58):9217-9224.

27. Ulitsky I, Maron-Katz A, Shavit S, Sagir D, Linhart C, Elkon R, Tanay A, Sharan R, Shiloh Y and Shamir R. Expander: from expression microarrays to networks and functions. Nature protocols. 2010; 5(2):303-322.

28. Paz A, Brownstein Z, Ber Y, Bialik S, David E, Sagir D, Ulitsky I, Elkon R, Kimchi A, Avraham KB, Shiloh Y and Shamir R. SPIKE: a database of highly curated human signaling pathways. Nucleic Acids Res. 2011; 39(Database issue):D793-799.

29. Wei L, Sandbulte MR, Thomas PG, Webby RJ, Homayouni $\mathrm{R}$ and Pfeffer LM. NFкB negatively regulates interferoninduced gene expression and anti-influenza activity. J Biol Chem. 2006; 281(17):11678-11684.

30. Pfeffer LM, Kim JG, Pfeffer SR, Carrigan DJ, Baker DP, Wei L and Homayouni R. The role of NF- $\kappa$ B in the antiviral action of interferon and interferon-regulated gene expression. J Biol Chem. 2004; 279(30):31304-31311. 